\title{
Salt Water Intrusion and Delineation of Groundwater Quality at Coastal Aquifers
}

\author{
M. V. Raju, M. Satish Kumar, Md. B. Wasim Akram, T. L. Rishi Vardhan, Hepsibah Palivela
}

\begin{abstract}
Ground water quality changes or depleting day by day due to various contaminated substances presence in the environment and also other factors influences of excessive drawing of ground water, intrusion of septic sewage, improper dumping of solid waste disposal, untreated industrial effluents, sludge and waste water disposal without giving any treatment and also seasonal changes, etc., all are leads to decrease the quality and depth of ground water table, which leads to cause severe health issues like diarrhea, dysentery, digestive problems etc., on human life. In this contest an attempt has been made to find the ground water quality and also to know the level of contamination presents in Akividu area. About 16 number of ground water samples were collected, which covers the entire area of Akividu, by the estimation of ground water quality parameters includes $\mathrm{pH}$, $\mathrm{CO}_{3}, \mathrm{HCO}_{3}, \mathrm{NH}_{3}, \mathrm{NO}_{2}{ }^{-}, \mathrm{DO}$, Salinity, Hardness, Chlorine, Total Alkalinity and Total Ammonia, during post monsoon months of October to November 2019. It was found that many of ground water samples have excess amount salinity and hardness and reaming parameters were in permissible range. All these accumulations of salinity (more than $0.5 \mathrm{ppm}$ ) and hardness (more than $600 \mathrm{ppm}$ ) may cause due to practices of aquaculture near and around the area of Akividu, and hence it is very necessary to done the periodical examination and also need to stop contaminate sources entering into nearby water bodies
\end{abstract}

Keywords: Effluents, Groundwater, Hardness, Quality, Salinity, Treatment.

\section{INTRODUCTION}

Water is natural resources of fundamental importance and is impartment in sustaining a healthy biosphere. Water is an internal medium for almost all organisms and principal external medium for several organisms. All organisms use water for their metabolic processes. Earth surface is covered by Seventy One percentage of water, from that about 96.3 percentage of water covered by oceans, which is not suitable for domestic purposes and remains available as 0.93

Revised Manuscript Received on February 08, 2020.

* Correspondence Author Vignans Fondation for Science Technology and Research, A.P., India

Dr. M. Satish Kumar, Professor, Department of Civil Engineering, Kallam Haranadha Reddy Institute of Technology, Guntur, A.P., India.

Md. B. Wasim Akram B.Tech, Student Dept. of Civil Engg., VFSTR, Guntur, A.P., India

T. L. Rishi Vardhan, B.Tech, Student Dept. of Civil Engg., VFSTR, Guntur, A.P., India

Dr. Hepsibah Palivela, UGC- Post Doctoral Fellow, Centre for Women Studies, Andhra University, Visakhapatnam, A.P., India

(C) The Authors. Published by Blue Eyes Intelligence Engineering and Sciences Publication (BEIESP). This is an open access article under the CC BY-NC-ND license (http://creativecommons.org/licenses/by-nc-nd/4.0/)
M. V. Raju, Assistant Professor, Department of Civil Engineering,

percentage of Saline ground water, 0.07 percentages as saline lake waters and 2.5 percentages available as fresh waters. From 2.5 percentages of fresh waters, 1.3 percentages of water available as surface water, 30.1 percentage as ground water and 68.6 percentage as Glaciers and ice caps . From 1.3 percentages of surface waters 20.1 percentages available in form of lakes remain $73.1 \%$ as Ice and snow mountains.

Ground water commonly understands as the water occupying all the voids with a geologic stratum. Water contained in saturated zones is important for water supply development. Under ground water plays an important role in overall water balance of the environment. As a reservoir, it has an enormous capacity to store water in rainy periods which can be utilized during dry periods; ground water is a primary source of fresh water in several towns and rural areas. At present protection of groundwater at coastal zones becomes more complex issue with respect to quality as these zones are contaminating due to the over lifting of water for various domestic and industrial needs[4] of nearby coastal areas due to which the saltwater enters into the freshwater aquifers and damages groundwater. The general global distribution of water on earth shown in figure 1

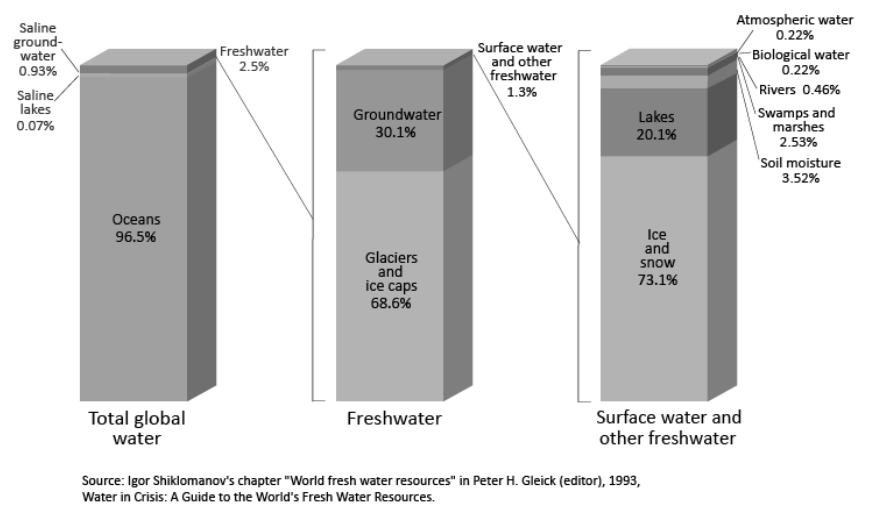

Figure 1 Distribution of water on earth

\section{ABOUT THE STUDY AREA}

Akividu is the one of the urban centre in district of west Godavari of Andhra Pradesh state and it is a one of the major semi-urban place in the coastal region of Andhra Pradesh. It's Coordinates at $16.6000^{\circ} \mathrm{N} 81.3833^{\circ} \mathrm{E}$. It is located in between rail route of Gudivada and Bhimavaram and is much connected with National Highway Number 214 (NH214). The town is with an average temperature of 28 degrees centigrade and annual rainfall of 103 centimeters 


\section{Salt Water Intrusion and Delineation of Groundwater Quality at Coastal Aquifers}

Akividu is one of the major panchayati in district of W.G. and it contains 15 revenue villages of Mandal head quarters. The town had a population of 24,506, with male population 11963 and female population about 12543 , and it stands with $73 \%$ of literacy rate. The area, where practicing more in aquaculture and more demand on domestic water supply, which leads to attentions on quality of water in and around the town. The location map of Akividu town shown in figure 1.

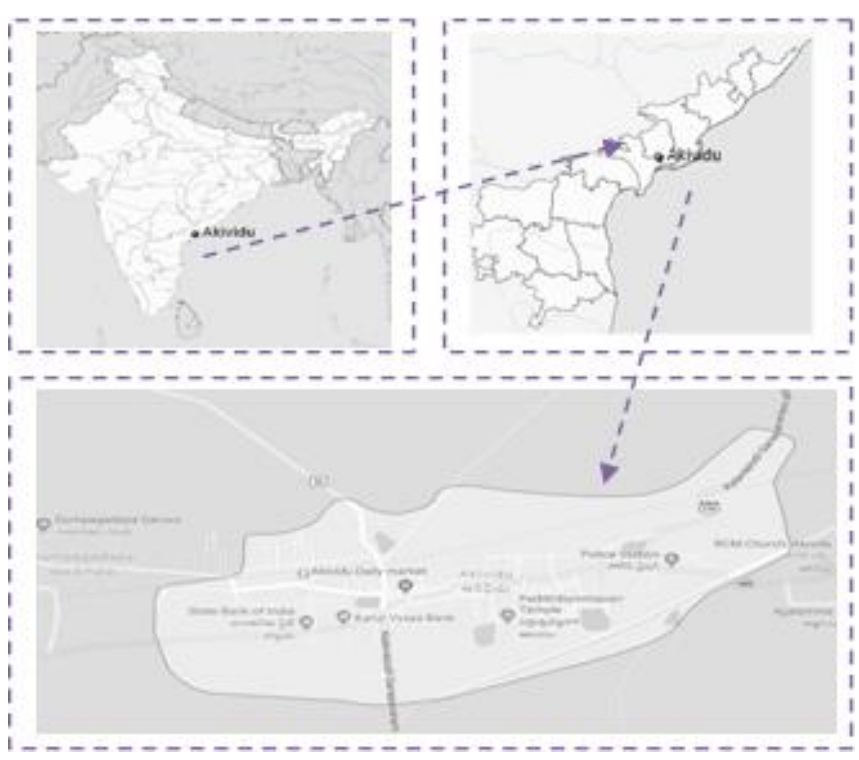

Figure 2. Location Map of the Akividu, W.G. Dist., Andhra Pradesh

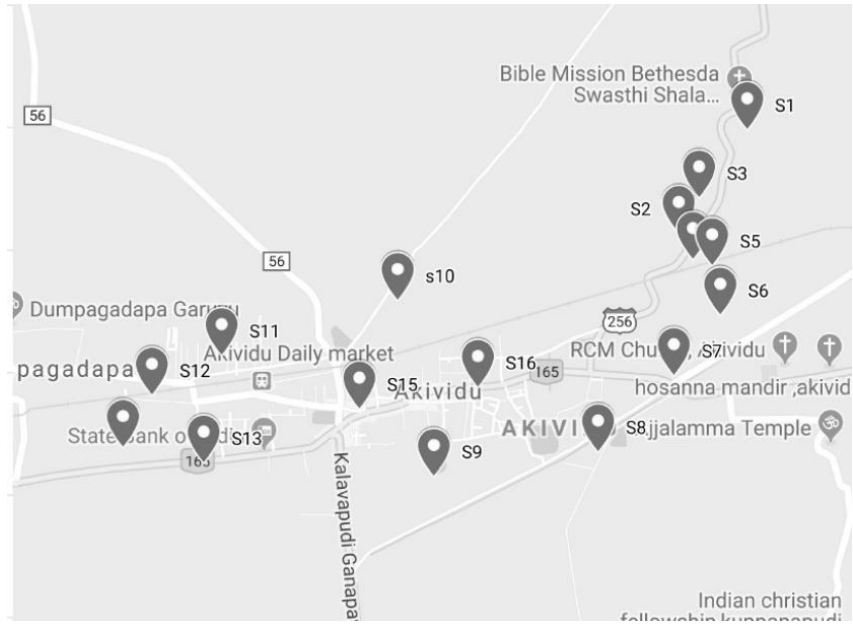

Figure 3. Ground Water Sampling Locations Map at Akividu, W.G. Dist., Andhra Pradesh

\section{OBJECTIVES}

Water is said to be polluted when it is unfit for its intended use. The quality of ground water [7] is an important as its quantity. A potable water supply, which is needed for the existence of a population, has to be in the right quantity and of right quality.

In the present study, the ground water quality in akividu areas Viz: Kalavapudi Ganapavaram Road, 16 building centre , MAA Kali Ice Plant area, Hope Baptist Church area , PP Road area, Market Area, Old Sivaalayam Road and many parts of akividu has been surveyed. The samples have been collected from dug wells and bore wells [10] for quality estimation. The objective of the present study is to access the ground water quality status [3] in the study area and its portability.

Table:1 Sampling Details at Akividu

\begin{tabular}{|c|c|c|c|}
\hline Sl.No. & $\begin{array}{l}\text { Sample } \\
\text { Details }\end{array}$ & $\begin{array}{c}\text { Area Details in } \\
\text { Akividu }\end{array}$ & $\begin{array}{l}\text { Location } \\
\text { Details }\end{array}$ \\
\hline 1 & S1 & $\begin{array}{l}\text { Kalavapudi } \\
\text { Ganapavaram Road }\end{array}$ & $\begin{array}{l}16^{\circ} 35^{\prime} 43.4^{\prime \prime N} \\
81^{\circ} 23^{\prime} 40.8^{\prime \prime} \mathrm{E}\end{array}$ \\
\hline 2 & S2 & 16 building centre & $\begin{array}{l}16^{\circ} 35^{\prime} 24.6^{\prime \prime N} \\
81^{\circ} 23^{\prime} 27.8^{\prime \prime} \mathrm{E}\end{array}$ \\
\hline 3 & S3 & MAA Kali Ice Plant & $\begin{array}{l}16^{\circ} 35^{\prime} 30.1^{\prime \prime N} \\
81^{\circ} 23^{\prime} 32.1^{\prime \prime} \mathrm{E}\end{array}$ \\
\hline 4 & S4 & $\begin{array}{l}\text { kalavapudi } \\
\text { ganapavaram road }\end{array}$ & $\begin{array}{l}16^{\circ} 35^{\prime} 19.9^{\prime \prime N} \\
81^{\circ} 23^{\prime} 30.5^{\prime \prime} \mathrm{E}\end{array}$ \\
\hline 5 & S5 & Akividu & $\begin{array}{l}16^{\circ} 35^{\prime} 18.8^{\prime \prime N} \\
81^{\circ} 23^{\prime} 34.1^{\prime \prime} \mathrm{E}\end{array}$ \\
\hline 6 & S6 & Akividu & $\begin{array}{l}16^{\circ} 35^{\prime} 09.8^{\prime \prime N} \\
81^{\circ} 23^{\prime} 35.7^{\prime \prime} \mathrm{E}\end{array}$ \\
\hline 7 & S7 & $\begin{array}{l}\text { Hope Baptist Church } \\
\text { area }\end{array}$ & $\begin{array}{l}16^{\circ} 34^{\prime} 58.9^{\prime \prime N} \\
81^{\circ} 23^{\prime} 26.9 " \mathrm{E}\end{array}$ \\
\hline 8 & S8 & Akividu & $\begin{array}{l}16^{\circ} 34^{\prime} 45.0^{\prime \prime N} \\
81^{\circ} 23^{\prime} 12.5^{\prime \prime} \mathrm{E}\end{array}$ \\
\hline 9 & S9 & Akividu & $\begin{array}{l}16^{\circ} 34^{\prime} 40.6^{\prime \prime N} \\
81^{\circ} 22^{\prime} 41.4^{\prime \prime} \mathrm{E}\end{array}$ \\
\hline 10 & S10 & Akividu & $\begin{array}{l}6^{\circ} 35 ' 12.5 " \mathrm{~N} \\
81^{\circ} 22^{\prime} 34.5^{\prime \prime} \mathrm{E}\end{array}$ \\
\hline 11 & S11 & Akividu & $\begin{array}{l}16^{\circ} 35^{\prime} 02.5^{\prime \prime N} \\
81^{\circ} 22^{\prime} 01.1^{\prime \prime} \mathrm{E}\end{array}$ \\
\hline 12 & S12 & Shanthi Nagar & $\begin{array}{l}16^{\circ} 34^{\prime} 55.3^{\prime \prime} \mathrm{N} \\
81^{\circ} 21^{\prime} 47.9^{\prime \prime} \mathrm{E}\end{array}$ \\
\hline 13 & S13 & PP Road & $\begin{array}{l}16^{\circ} 34^{\prime} 43.0^{\prime \prime} \mathrm{N} \\
81^{\circ} 21^{\prime} 57.7^{\prime \prime} \mathrm{E}\end{array}$ \\
\hline 14 & S14 & Akividu & $\begin{array}{l}16^{\circ} 34^{\prime} 45.8^{\prime \prime N} \\
81^{\circ} 21^{\prime} 42.4^{\prime \prime} \mathrm{E}\end{array}$ \\
\hline 15 & S15 & $\begin{array}{l}\text { Akividu Market } \\
\text { Area }\end{array}$ & $\begin{array}{l}16^{\circ} 34^{\prime} 52.8^{\prime \prime N} \\
81^{\circ} 22^{\prime} 27.2^{\prime \prime} \mathrm{E}\end{array}$ \\
\hline 16 & S16 & $\begin{array}{l}\text { Old Sivaalayam } \\
\text { Road }\end{array}$ & $\begin{array}{l}16^{\circ} 34^{\prime} 56.7^{\prime \prime N} \\
81^{\circ} 22^{\prime} 49.7^{\prime \prime} \mathrm{E}\end{array}$ \\
\hline
\end{tabular}

\section{MATERIALS AND METHODS}

16 Ground Water samples have been collected Kalavapudi Ganapavaram Road, 16 building centre , MAA Kali Ice Plant area, Hope Baptist Church area , PP Road area, Market Area, Old Sivaalayam Road and many parts of akividu , during post monsoon months of October to November 2019. Sampling location details shown in table 1

Ground water Samples were collected [9] according to procedures of UNESCO. And clearly give details, where the samples were collected. Parameters includes $\mathrm{pH}, \mathrm{CO}_{3}, \mathrm{HCO}_{3}$, $\mathrm{NH}_{3}, \mathrm{NO}_{2}^{-}$, DO, Salinity, Hardness, Chlorine, Total Alkalinity and Total Ammonia were by estimated by standard methods [6] of APHA (1998). Methods used for the estimation of ground water samples shown in table 2 . And few samples collection and estimation shown in figure 4 
Table 2 Methods followed for estimation of ground water samples (APHA) 1998

\begin{tabular}{|l|l||}
\hline $\begin{array}{l}\text { Name of the } \\
\text { Parameter }\end{array}$ & Method Used for Quality \\
\hline \hline Temperature $\left({ }^{0} \mathrm{C}\right)$ & $\begin{array}{l}\text { Precision thermometer, measured } \\
\text { in situ }\end{array}$ \\
\hline \hline EC (Mhoms) & Conductivity meter \\
\hline \hline Turbidity (NTU) & Nephelo meter \\
\hline TS (mg/l) & Evaporation process \\
\hline TDS(mg/l) & Evaporation and filtration \\
\hline pH (range) & Digital pH meter \\
\hline $\begin{array}{l}\text { Total Alkalinity } \\
(\mathrm{CaCO})(\mathrm{mg} / \mathrm{l})\end{array}$ & Titration Process \\
\hline $\begin{array}{l}\text { Phenolphthalein } \\
\text { Alkalinity }(\mathrm{CaCO} \\
\text { (mg/l) }\end{array}$ & Titration Process \\
\hline \hline
\end{tabular}
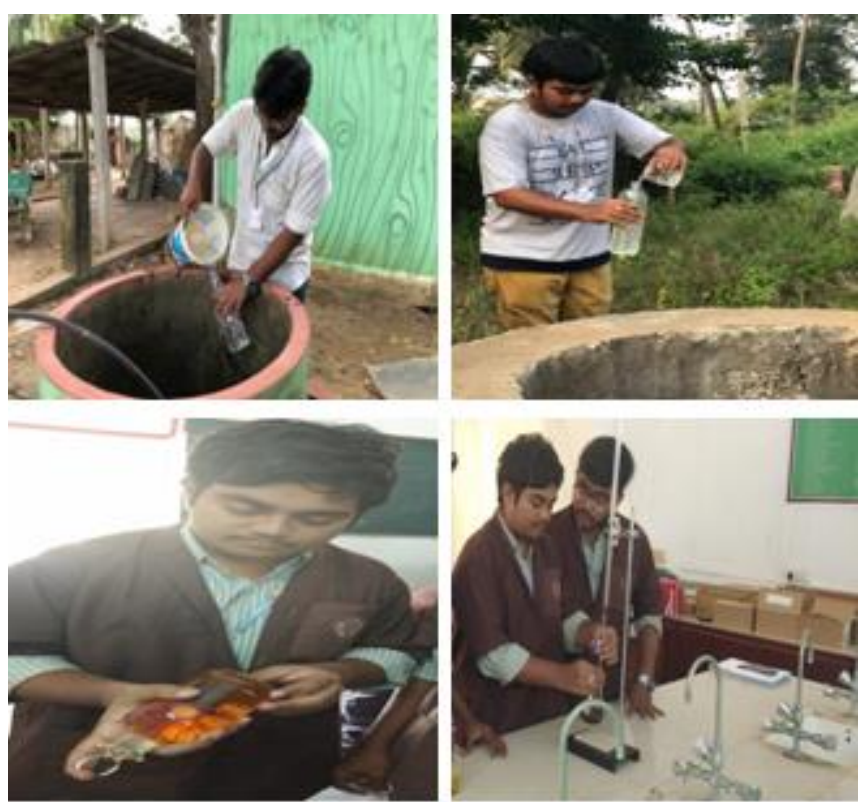

Figure 4. Images of few Samples Collections and Estimation

\section{RESULTS AND DISCUSSIONS}

The determination included chemical quality parameters[2] for ground water samples with 16 ground water samples collected at various wells/bore, which covers total area [10] of Akividu area and sampling has been done during post monsoon months of October to November 2019. Salinity is increasing in ground water samples \{i.e. S1,S4,S5,S7,S8,S9,S14,S15,S16 = 1 ppm avg. salinity $\}$ and hardness is more than desirable limits in ground water samples \{i.e. S2,S3,S6,S10,S11,S12,S13 \} and more than permissible limits in ground water samples \{i.e. S1,S5,S6,S10,S13,S14 =1080 ppm,725 ppm, 680 ppm, 1080 ppm, 1080 ppm, 885 ppm \} and pH, salinity in remaining samples, Carbonates, Bi-Carbonates, Total Alkalinity, Total Ammonia, $\mathrm{NH}_{3}$,Nitrites, Dissolved Oxygen, Hardness in remaining samples, Chlorine are less than their desirable limits. The optimum standard values were shown in table 3 and results are showed in table 4. And graphical representation of major quality parameters salinity and hardness are shown in Figure 5 and figure 6 respectively.

Table 3 Optimum standards levels for various samples

\begin{tabular}{||l|c||}
\hline \multicolumn{1}{|c|}{$\begin{array}{c}\text { Name of Chemical } \\
\text { Parameter }\end{array}$} & $\begin{array}{c}\text { Optimum Standard } \\
\text { value }\end{array}$ \\
\hline \hline pH & $6.5-8.5$ \\
\hline \hline Salinity (ppm) & $<0.5$ \\
\hline \hline CO3 (ppm) & No Limits \\
\hline \hline HCO3 (ppm) & \\
\hline \hline $\begin{array}{l}\text { Total } \\
\text { Alkalinity (ppm) }\end{array}$ & $200-600$ \\
\hline \hline $\begin{array}{l}\text { Total } \\
\text { Ammonia (ppm) }\end{array}$ & $0.25-32.5$ \\
\hline \hline NH3 (ppm) & $45-100$ \\
\hline \hline NO2- (ppm) & $45-100$ \\
\hline \hline DO (ppm) & $<2$ \\
\hline \hline Hardness (ppm) & $300-600$ \\
\hline \hline Chlorine (ppm) & $250-100$ \\
\hline
\end{tabular}

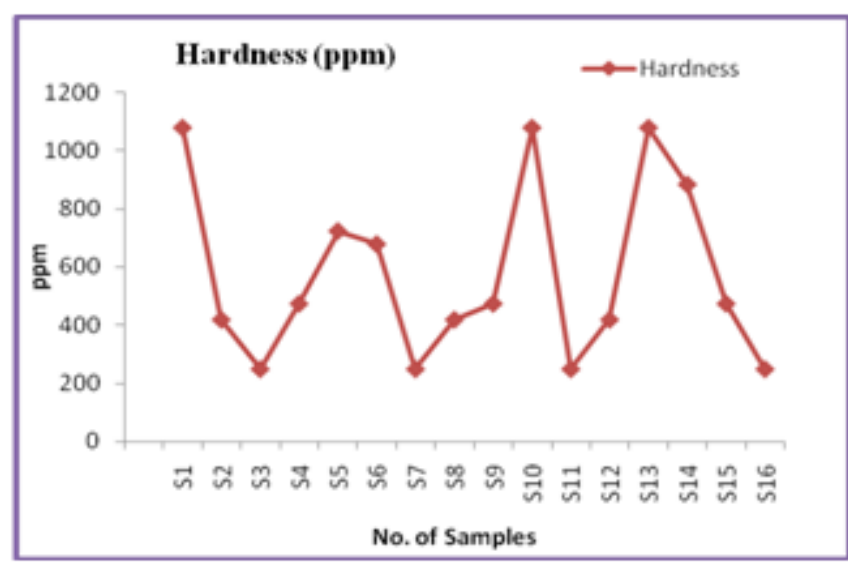

Figure 5. Graphical representation of Salinity of respective samples

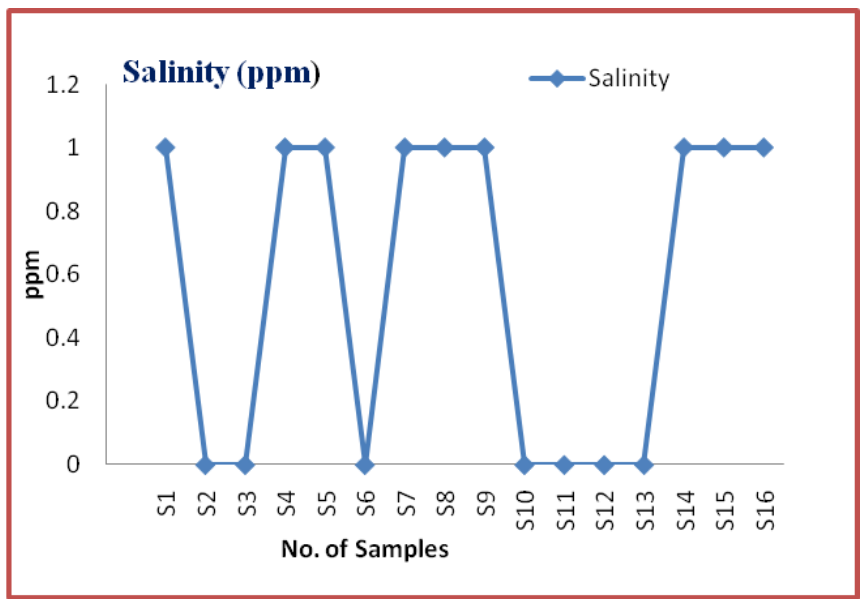

Figure 6. Graphical representation of Hardness of respective samples

Published By: 
Salt Water Intrusion and Delineation of Groundwater Quality at Coastal Aquifers

Table 4. Quality Characteristics of Ground Water at Study Area

\begin{tabular}{|c|c|c|c|c|c|c|c|c|c|c|c|c|}
\hline \multirow{2}{*}{$\begin{array}{l}\text { Sl. } \\
\text { No. }\end{array}$} & \multirow[b]{2}{*}{$\begin{array}{c}\text { Sample } \\
\text { Code } \\
\end{array}$} & \multicolumn{11}{|c|}{ Chemical Quality Characteristics (Units = ppm, except pH) } \\
\hline & & $\mathrm{pH}$ & Salinity & $\mathrm{CO}_{3}$ & $\mathrm{HCO}_{3}$ & $\begin{array}{c}\text { Total } \\
\text { Alkalinity } \\
\end{array}$ & $\begin{array}{c}\text { Total } \\
\text { Ammonia } \\
\end{array}$ & $\mathrm{NH}_{3}$ & $\mathrm{NO}_{2}^{-}$ & DO & Hardness & Chlorine \\
\hline 1 & S1 & 8.4 & 1 & 0 & 135 & 135 & 0.25 & Nil & Nil & 4.8 & 1080 & Nil \\
\hline 2 & $\mathrm{~S} 2$ & 7.8 & 0 & 10 & 125 & 135 & $\mathrm{Nil}$ & Nil & $\mathrm{Nil}$ & 4.2 & 420 & Nil \\
\hline 3 & S3 & 8.5 & 0 & 0 & 90 & 90 & $\mathrm{Nil}$ & Nil & Nil & 5.4 & 250 & Nil \\
\hline 4 & S4 & 7.6 & 1 & 5 & 105 & 110 & 0.1 & Nil & Nil & 5.2 & 475 & Nil \\
\hline 5 & S5 & 8.4 & 1 & 0 & 115 & 115 & $\mathrm{Nil}$ & Nil & $\mathrm{Nil}$ & 6.2 & 725 & Nil \\
\hline 6 & S6 & 7.8 & 0 & 5 & 100 & 105 & $\mathrm{Nil}$ & Nil & Nil & 4.7 & 680 & Nil \\
\hline 7 & S7 & 8.1 & 1 & 5 & 95 & 100 & 0.15 & Nil & Nil & 6.3 & 250 & Nil \\
\hline 8 & S8 & 8.4 & 1 & 10 & 110 & 120 & $\mathrm{Nil}$ & Nil & Nil & 4.8 & 420 & 0.01 \\
\hline 9 & S9 & 8.4 & 1 & 5 & 90 & 95 & $\mathrm{Nil}$ & Nil & Nil & 5.2 & 475 & 0.01 \\
\hline 10 & $\mathrm{~S} 10$ & 7.6 & 0 & 0 & 135 & 135 & $\mathrm{Nil}$ & Nil & Nil & 5 & 1080 & $\mathrm{Nil}$ \\
\hline 11 & S11 & 7.6 & 0 & 0 & 125 & 125 & $\mathrm{Nil}$ & Nil & Nil & 3.4 & 250 & Nil \\
\hline 12 & $\mathrm{~S} 12$ & 7.8 & 0 & 10 & 95 & 105 & $\mathrm{Nil}$ & Nil & Nil & 6 & 420 & Nil \\
\hline 13 & $\mathrm{~S} 13$ & 8.4 & 0 & 5 & 115 & 120 & $\mathrm{Nil}$ & Nil & Nil & 4.8 & 1080 & 0.01 \\
\hline 14 & S14 & 7.6 & 1 & 10 & 115 & 125 & 0.05 & Nil & Nil & 5.8 & 885 & $\mathrm{Nil}$ \\
\hline 15 & $\mathrm{~S} 15$ & 8.4 & 1 & 0 & 110 & 110 & $\mathrm{Nil}$ & Nil & Nil & 5.2 & 475 & 0.01 \\
\hline 16 & S16 & 8.4 & 1 & 5 & 105 & 110 & 0.25 & Nil & Nil & 6.5 & 250 & $\mathrm{Nil}$ \\
\hline
\end{tabular}

\section{CONCLUSIONS}

Water supply is one of the factors of fundamental importance of dwellers, who require 135 liters per head per day for their domestic activities. The ground water quality in the Akividu of West Godavari district has been monitored and the ground water quality in Akividu area, few sources at Kalavapudi Ganapavaram Road, Akividu, Hope Baptist Church area, few parts of Akividu has high concentrations of Salinity , range of $1 \mathrm{ppm}$ and Hardness, ranges from $680 \mathrm{ppm}$, to $1080 \mathrm{ppm}$, which were more than permissible limits and indicating that the ground water in few areas of Akividu town is unsatisfactory with respect to quality parameters that had been estimated. For direct consumption of water is not recommended [8] due to excessive amounts of salinity and hardness content and treatment must be given [5] before utilization and also require periodical monitoring of ground waters.

\section{REFERENCES}

1. APHA, Standard Methods for the examination of water and waste water. Washington, DC: American public health Association, 1992, 326.

2. Satish Kumar, M., Raju, M.V., Palivela, H., (2017) Comprehensive index of groundwater prospects by using standard protocols - A model study, International Journal of Civil Engineering and Technology , Volume 8, Issue 5, pp. 521 to526

3. BIS, Indian standard drinking water specifications IS10500:1991, edition 2.2(2003), New Delhi

4. Kumar, M.S., Raju, M.V., Palivela, H., Venu Ratna Kumari, G. (2017) , Water quality scenario of urban polluted lakes - A model study,
International Journal of Civil Engineering and Technology, Volume 8(5), pp. 297 to 302

5. Prasadini, T.V., Srinivasu, N., Raju, M.V.(2019) The future of chlorine disinfectant choice in rural areas, International Journal of Innovative Technology and Exploring Engineering, 8(8), pp. 1813-1817

6. Kumar, M.S., Raju, M.V., Babu, S.R., Kumar, M.S.J., (2017) Interpretation and correlative study of water simulation in surface water bodies, International Journal of Civil Engineering and Technology, Volume 8, Issue 5, pp. 1206 to1211

7. Madhuri, T.U. (2015) A study on assessment of groundwater quality and its suitability for drinking in Madhurawada, Visakhapatnam, Indian Journal of Environmental Protection, Volume 35, Issue 2, Pages 138-143

8. Sanjay Sharma and Mathur R, (1995) Seasonal changes in groundwater quality in Gwalior: Health risk assessment. Pollution Research 14 (4) 373 to 376

9. Venu Ratna Kumari, G.,Kumar, M.S., Raju, M.V., Palivela, H., (2018), A synoptical representation on potentiality of ground water using geo spatial technology, International Journal of Civil Engineering and Technology , Volume 9, Issue 1, , pp. 748-754

10. Raju M.V., Kumar, M.S., G.V.R. kumari, Babu S.R., (2018), An investigative study on water quality distribution in the zones of municipal corporation using remote sensing and GIS applications, International Journal of Civil Engineering and Technology , Volume 9, Issue 6, , pp. 1182 to1190

\section{AUTHORS PROFILE}

M. V. Raju, M.Tech from JNT University, Kukatpally, Hyderabad, and Assistant Professor, Department of Civil Engineering, VFSTR, Deemed to be University, Vadlamudi, Guntur, A.P., India .

Published By: 
Dr. Satish Kumar Moparthi, is Professor of Civil Engineering, Kallam Haranadha Reddy Institute of Technology, Guntur, Andhra Pradesh, India.

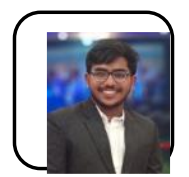

Md. B. Wasim Akram, Student of B.Tech., Department of Civil Engineering, Vignans Foundation for Science Technology and Research, Deemed to be University, Vadlamudi, Guntur, Andhra Pradesh, India.

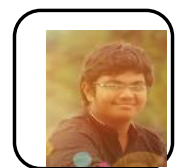

T. L. Rishi Vardhan, Student of B.Tech., Department of Civil Engineering, Vignans Foundation for Science Technology and Research, Deemed to be University, Vadlamudi, Guntur, Andhra Pradesh, India

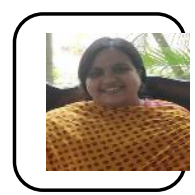

Dr. Hepsibah Palivela, is the UGC - Post Doctoral Fellow, Centre for Women Studies, Andhra University. Visakhapatnam, A.P. India. She has published more than 22 Research Publications indexed in various SCI/Scopus Cited Journals 